\title{
Synthesis, Spectral, Thermal and Magnetic Studies of Chromium and Molybdenum Carbonyl Complexes Containing N2O2 Donor Sites
}

\author{
Omyma A.M. Ali ${ }^{1 *}$, Ramadan M. Ramadan ${ }^{2}$, Abeer S.S. Sayed 1 \\ ${ }^{1}$ Chemistry Department, Faculty of Women for Arts, Science and Education, Ain Shams University, Cairo, Egypt. \\ ${ }^{2}$ Chemistry Department, Faculty of Science, Ain Shams University, Cairo, Egypt
}

*Corresponding Author: Omyma A. M. Ali, Chemistry Department, Faculty of Women for Arts, Ain Shams University, Cairo, Egypt

\begin{abstract}
Cr}(\mathrm{CO})_{6}$ reacts with bis-(salicylaldehyde) ethylendiimine ( salen $\left._{2}\right)$ in $\mathrm{THF}$ under reduced pressure in the presence of thiourea (Tu) to give the monocarbonyl complex $[\mathrm{Cr}(\mathrm{CO})($ salen $)(\mathrm{Tu})](\mathbf{1})$. In the presence of triphenylphosphine $\left(\mathrm{PPh}_{3}\right)$ or 2-aminobenzothiazole (Abtz), the corresponding reaction gives $[\mathrm{Cr}(\mathrm{salen})(L)](L=$ $\mathrm{PPh}_{3}(\mathbf{2})$ or Abtz (3)). Three complexes with molecular formulas $\left[\mathrm{Mo}(\mathrm{CO})\left(\mathrm{salenH}_{2}\right)\left(\mathrm{PPh}_{3}\right)\right](4)$ and $\left[\mathrm{Mo}\left(\operatorname{salenH}_{2}\right)(\mathrm{L})\right]\left(\mathrm{L}=\mathrm{Tu}(5)\right.$ or Abtz (6)) were isolated from the reactions with $\mathrm{Mo}(\mathrm{CO})_{6}$. All synthesized compounds were identified and confirmed by elemental analyses, spectral (UV-Vis, IR, ${ }^{1} H N M R$, mass) and magnetic moment measurements. The thermal behavior of these complexes was investigated and the thermal decomposition pathways have been postulated showing that the final product is metal oxide. The activation thermodynamic parameters; $E^{*}, H^{*}, S^{*}$ and $G^{*}$ for the different thermal decomposition steps of the complexes were calculated using Coats-Redfern equation.
\end{abstract}

Keywords: Complexes; Carbonyl; Molybdenum; Thermal analysis.

\section{INTRODUCTION}

Transition metal compounds containing Schiff base ligands have been of great interest for many years [1]. In particular, complexes with $\mathrm{N}_{2} \mathrm{O}_{2}$ Schiff bases have been widely reported [2-4] and used as biological models to understand the structures of biomolecules and biological processes [5,6]. Their instant and enduring popularity undoubtedly stems from the ease with which they can be synthesized, their puzzling versatility and their wide ranging complexing ability once formed. These compounds play an important role in the coordination chemistry related to catalysis and enzymatic reactions, magnetism and molecular architectures [7]. Not only have they played a seminal role in the development of modern co-ordination chemistry [8], but they can also be found at key points in the development of inorganic biochemistry [9], catalysis $[\mathbf{1 0}, \mathbf{1 1}]$, medical imaging [12], optical materials [13] and thin films $[\mathbf{1 4}, \mathbf{1 5}]$. As a continuation of our previous work dealing with the study of the interaction of metal carbonyl with Schiff bases [16-21], we report here the synthesis and characterization of $\mathrm{M}(\mathrm{CO})_{6}(\mathrm{M}=\mathrm{Cr}$ or Mo) with bis-(salicylaldehyde) ethylendiimine $\left(\mathrm{salenH}_{2}\right)$ in presence of 2-aminobenzothiazole, thiourea or triphenylphosphine.

\section{EXPERIMENTAL}

\subsection{Reagents}

The hex carbonyls of chromium and molybdenum were supplied by Aldrich. 2-aminobenzothiazole, thiourea and triphenylphosphine were supplied from British Drug House (BDH). Bis-(2-salicylaldehyde) ethylenediimine (salenH2) was prepared as described in the literature [22]. All solvents were purified by distillation before use.

\subsection{Instruments}

Infrared measurements were carried out on a Unicom-Mattson 1000 FT-IR spectrometer using $\mathrm{KBr}$ pellets. Nuclear magnetic resonance measurements were preformed on a Varian Mercury $300 \mathrm{MHz} \mathrm{NMR}$

International Journal of Advanced Research in Chemical Science (IJARCS) Page |1 
spectrometer. The samples were dissolved in DMSO, d6 and tetramethylsilane (TMS) was used as an internal reference. Magnetic susceptibility measurements of the paramagnetic complexes in the solid state (Gouy method) were performed on a Sherwood Scientific Magnetic Susceptibility Balance. Electron spin resonance spectra of the powdered paramagnetic complexes were carried out on a Bruker, Electron Spin Resonance Spectrometer model EMX. UV-vis spectra were measured on a Unicam UV2-300 spectrophotometer. Measurements of the thermo gravimetric analysis (TG) were carried out under nitrogen atmosphere with a heating rate of $10{ }^{\circ} \mathrm{C} / \mathrm{min}$. using a Shimadzu DT-50 thermal analyzer. The complexes were also characterized by elemental analysis (Perkin-Elmer $2400 \mathrm{CHN}$ elemental analyzer) and mass spectroscopy (Finnigan MAT SSQ 7000). Table 1 gives the elemental analysis and mass spectrometry data for the complexes.

Table1. Elemental analysis, Color, \% of yield and mass spectrometry data for the complexes

\begin{tabular}{|c|c|c|c|c|c|c|c|c|}
\hline \multirow[t]{2}{*}{ Complex } & \multirow[t]{2}{*}{ Color } & \multirow[t]{2}{*}{\begin{tabular}{|l} 
Reaction \\
period (h)
\end{tabular}} & \multirow[t]{2}{*}{$\begin{array}{c}\text { Yield } \\
(\%)\end{array}$} & \multicolumn{3}{|c|}{$\begin{array}{l}\text { Elemental analysis data } \\
\text { Found (Calcd.) }\end{array}$} & \multicolumn{2}{|c|}{$\begin{array}{c}\text { Mass } \\
\text { spectrometry }\end{array}$} \\
\hline & & & & $\% \mathrm{C}$ & $\% \mathrm{H}$ & $\% \mathrm{~N}$ & M. wt. & $\mathbf{m} / \mathbf{z}$ \\
\hline$[\mathrm{Cr}(\mathrm{CO})($ & $\begin{array}{c}\text { light } \\
\text { brown }\end{array}$ & 3 & 52 & $51.30(51.17)$ & $4.55(4.29)$ & $13.25(13.26)$ & 422.42 & $\begin{array}{l}395[\mathrm{P}- \\
\mathrm{CO}]^{+}\end{array}$ \\
\hline$[\mathrm{Cr}($ salen$)(\mathrm{PPh} 3)](2)$ & gray & 2 & 41 & $70.44(70.34)$ & $4.95(5.03)$ & $4.75(4.82)$ & 580.55 & $581[\mathrm{P}]^{+}$ \\
\hline$[\mathrm{Cr}($ salen $)(\mathrm{Abtz})](3)$ & $\begin{array}{c}\text { pale } \\
\text { brown }\end{array}$ & 5 & 55 & $58.80(58.96)$ & $4.50(4.30)$ & $11.86(11.96)$ & 468.48 & $469[\mathrm{P}]^{+}$ \\
\hline $\begin{array}{c}{[\mathrm{Mo}(\mathrm{CO})(\text { salenH} 2)(\mathrm{PPh} 3)]} \\
(4)\end{array}$ & $\begin{array}{c}\text { dark } \\
\text { brown }\end{array}$ & 2 & 50 & $64.50(64.22)$ & $4.50(4.77)$ & $4.40(4.28)$ & 54.53 & $\begin{array}{c}627[\mathrm{P}- \\
\mathrm{CO}]^{+}\end{array}$ \\
\hline$[\mathrm{Mo}(\mathrm{salenH} 2)(\mathrm{Tu})](5)$ & $\begin{array}{c}\text { dark } \\
\text { brown }\end{array}$ & 2 & 34 & $46.50(46.37)$ & $4.50(4.57)$ & $12.50(12.72)$ & 440.37 & $441[\mathrm{P}]^{+}$ \\
\hline$[\mathrm{Mo}($ salenH2)(Abtz)] (6) & brown & 2 & 46 & $53.55(53.70)$ & $4.25(4.31)$ & $10.70(10.89)$ & 514.44 & $514[\mathrm{P}]^{+}$ \\
\hline
\end{tabular}

\subsection{Synthesis Of Complexes}

A general procedure was employed for the synthesis of the reported complexes. A mixture of equimolar amounts of $\mathrm{M}(\mathrm{CO}) 6, \mathrm{M}=\mathrm{Cr}$ or $\mathrm{Mo}$, salenH2 in the presence of a second ligand $\mathrm{Tu}$ or $\mathrm{PPh} 3$ or Abtz were mixed together in about $30 \mathrm{ml}$ THF. The reaction mixture was then degassed and then heated to reflux under the reduced pressure. The solvent was removed on a vacuum line. The residue was washed several times with petroleum ether and then recrystallized from DMF. The complex was left to dry in vacuo for several hours. Table 1 gives the reaction period, color of complex and \% yield.

\subsection{Antimicrobial Activity}

The in-vitro growth inhibitory of salenH2 and their complexes were performed against the bacterial species Staphylococcus aureus and Escherichia coli in Mueller Hinton-Agar medium. The antifungal activity was tested against the fungi Aspergillus flavus and Candida albicans cultured on YPD-agar medium. The test compounds were dissolved in DMSO at concentration $20 \mathrm{mg} / \mathrm{ml}$. Antibacterial activities of each compound were evaluated by the disc-diffusion method. The well ( $8 \mathrm{~mm}$ diameter) was then filled with the test solution and the plates were inoculated at $37^{\circ} \mathrm{C}$ for $48 \mathrm{~h}$ (for bacteria) and $30^{\circ} \mathrm{C}$ for $72 \mathrm{~h}$ (for fungi). During this period, the growth of the inoculated microorganisms was affected and then the inhibition zones developed on the plates were measured. The effectiveness of an antimicrobial agent was assessed by measuring the zones of inhibition around the well. The diameter of the zone is measured to the nearest millimeter $(\mathrm{mm})$. The antibacterial activity of each compound was compared with that of standard antibiotics such as Tetracycline. The antifungal activity of the test compound was compared that of Amphotericin B as standard antifungal. DMSO was used as a control under the same conditions for each organism and no activity was found. The activity results were calculated as a mean of triplicates.

\section{RESULTS AND DISCUSSION}

Formation of the complexes can be symbolized as follows: 


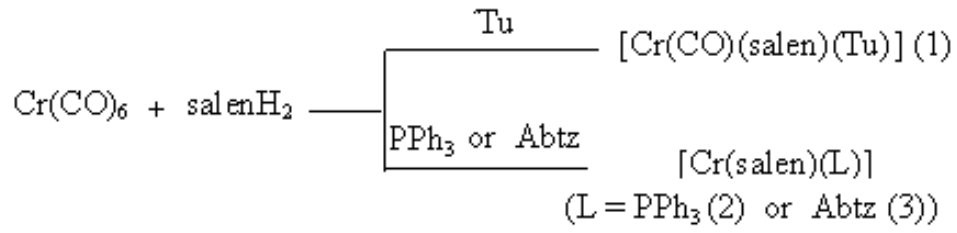

$$
\begin{aligned}
& \mathrm{Mo}(\mathrm{CO})_{6}+\operatorname{salenH_{2}} \begin{array}{ll}
\mathrm{PPh}_{3} & {\left[\mathrm{Mo}(\mathrm{CO})\left(\operatorname{salenH}_{2}\right)\left(\mathrm{PPh}_{3}\right)\right](4)} \\
\text { Tu or } \mathrm{Abtz} & {[\mathrm{Mo}(\operatorname{salenH})(\mathrm{L})]}
\end{array} \\
& (\mathrm{L}=\mathrm{Tu}(5) \text { or Abtz (6)) }
\end{aligned}
$$

The analytical and mass data of the complexes (Table 1) agree very well with the proposed molecular formula.

\subsection{IR Spectra And Mode Of Bonding}

IR spectra give enough information to elucidate the way of bonding of the ligands to the metal. The important IR spectral data of the free ligands and their complexes are presented in Table 2 . The free Schiff base ligand salenH 2 showed a strong band at $1634 \mathrm{~cm}-1$ and a medium band at $1577 \mathrm{~cm}-1$ due to the azomethine group. Coordination of the salenH 2 to the metal through the nitrogen atom is expected to reduce the electron density in the azomethine link and lower the $v \mathrm{C}=\mathrm{N}$ absorption frequency. The bands due to $v \mathrm{C}=\mathrm{N}$ are shifted to lower frequencies in the complexes indicating coordination Schiff base through the azomethine nitrogen [23]. A strong band observed at $1285 \mathrm{~cm}-1$ in salenH2 has been assigned to phenolic C-O stretching. On complexation, this band is shifted to a higher frequency indicating coordination through the phenolic oxygen (Table 2). The coordination of the azomethine nitrogen and phenolic oxygen are further supported by the appearance of two new bands at 473-526 and 408-462 cm-1 due to $v \mathrm{M}-\mathrm{O}$ and $v \mathrm{M}-\mathrm{N}$ respectively. The spectra of the two complexes $[\mathrm{Cr}(\mathrm{CO})(\mathrm{salen})(\mathrm{Tu})](1)$ and [Mo(CO)(salenH2)(PPh3)] (4) are dominated by a sharp band at 2100 and $1941 \mathrm{~cm}-1$, respectively due to a terminal $\vee C O$ group [23]. Also, IR spectrum of salenH2 ligand shows a broad band at $3445 \mathrm{~cm}-1$ may be attributed to phenolic $\mathrm{OH}$ group. This band was disappeared in chromium complexes 1-3 indicating that the ligand coordinated to the metal oxidatively with displacement of the $\mathrm{OH}$ protons [24]. Reaction of $\mathrm{Cr}(\mathrm{CO}) 6$ with the tetra dentate Schiff base bis (salicylaldehyde) phenylenediimine (salphenH2) yielded the dicarbonyl derivative $\mathrm{Cr}(\mathrm{CO}) 2$ (salphen). The ligand binds to the metal similarly with proton displacement giving the metal a +2 oxidation state [25]. In molybdenum complexes $4-6$, this band was shifted to lower frequency region at 3423-3427 cm-1 suggesting their involvement in coordination to molybdenum and the ligand acts as neutral tetradentate ONNO sphere [26]. All characteristic bands due to $\mathrm{Tu}, \mathrm{PPh} 3$ and Abtz are also present in the expected regions (Table 2). Scheme 1 gives the proposed structure of the chromium and molybdenum complexes.

\begin{tabular}{|c|c|c|c|c|c|c|c|c|c|}
\hline \multirow[t]{2}{*}{ Compound } & \multicolumn{9}{|c|}{ IR data(cm-1)a } \\
\hline & $\square$ (OH) & $\square(\mathbf{C O})$ & $\square(\mathbf{C}=\mathbf{N})$ & \begin{tabular}{|l|}
$\square$ (G-O) \\
\end{tabular} & $\square$ (NH) & $\square(\mathbf{C}=\mathbf{S})$ & $\begin{array}{c}\square \text { (G- } \\
\text { H)phos }\end{array}$ & $\begin{array}{l}\square \text { (MF } \\
\mathbf{O})\end{array}$ & $\begin{array}{l}\square(\mathbf{M} \\
\mathbf{N})\end{array}$ \\
\hline salenH2 & $3445(b)$ & - & \begin{tabular}{|c|}
$1634(\mathrm{~s})$ \\
$1577(\mathrm{~m})$
\end{tabular} & $1285(\mathrm{~s})$ & - & - & - & - & - \\
\hline $\mathrm{Tu}$ & - & - & - & - & $\begin{array}{c}3379(\mathrm{~s}) \\
3274(\mathrm{~s}) \\
3174(\mathrm{~s}) \\
3065(\mathrm{sh})\end{array}$ & $1417(\mathrm{~m})$ & - & - & - \\
\hline $\mathrm{PPh} 3$ & - & - & - & - & - & - & $\begin{array}{c}1475(\mathrm{~m}) \\
1432(\mathrm{~m}) \\
746(\mathrm{~s}) \\
695(\mathrm{~s})\end{array}$ & - & - \\
\hline
\end{tabular}

Table2. The important IR data of ligands and their complexes

International Journal of Advanced Research in Chemical Science (IJARCS) 
Synthesis, Spectral, Thermal and Magnetic Studies of Chromium and Molybdenum Carbonyl Complexes Containing N2O2 Donor Sites

\begin{tabular}{|c|c|c|c|c|c|c|c|c|c|}
\hline Abtz & - & - & $1650(\mathrm{~s})$ & - & $\begin{array}{l}3397(\mathrm{~s}) \\
3274(\mathrm{w})\end{array}$ & - & - & - & - \\
\hline$[\mathrm{Cr}(\mathrm{CO})($ salen$)(\mathrm{Tu})](1)$ & - & $2100(\mathrm{~s})$ & \begin{tabular}{|l|}
$1630(\mathrm{~s})$ \\
$1599(\mathrm{~s})$
\end{tabular} & $1295(\mathrm{~m})$ & $\begin{array}{l}3286(\mathrm{sh}) \\
3220(\mathrm{sh}) \\
3079(\mathrm{sh})\end{array}$ & $1405(w)$ & - & 474(m) & $409(w)$ \\
\hline$[\mathrm{Cr}($ salen $)(\mathrm{PPh} 3)](2)$ & - & - & \begin{tabular}{|c|}
$1633(\mathrm{~s})$ \\
$1597(\mathrm{~m})$
\end{tabular} & 1294(s) & - & - & $\begin{array}{l}1478(\mathrm{~s}) \\
1450(\mathrm{~s}) \\
758(\mathrm{~m})\end{array}$ & 523(m) & $460(\mathrm{sh})$ \\
\hline$[\mathrm{Cr}($ salen$)(\mathrm{Abtz})](3)$ & - & - & \begin{tabular}{|c|}
$1633(\mathrm{~s})$ \\
$1598(\mathrm{~m})$
\end{tabular} & $1296(\mathrm{~m})$ & $3286(\mathrm{sh})$ & - & - & 524(m) & $409(w)$ \\
\hline$\underset{(4)}{\left[\mathrm{Mo}(\mathrm{CO})\left(\operatorname{salenH}^{2}\right)(\mathrm{PPh} 3)\right]}$ & 3423(b) & 1941(m) & \begin{tabular}{|l|}
$1627(\mathrm{~m})$ \\
$1610(\mathrm{~m})$
\end{tabular} & $1286(\mathrm{~m})$ & - & - & $\begin{array}{c}1480(\mathrm{~m}) \\
1451(\mathrm{~m}) \\
755(\mathrm{~s}) \\
707(\mathrm{sh})\end{array}$ & $526(w)$ & $462(w)$ \\
\hline$[\mathrm{Mo}($ salenH2)(Tu)] (5) & 3426(b) & - & \begin{tabular}{|l|}
$1621(\mathrm{~s})$ \\
$1547(\mathrm{~s})$
\end{tabular} & $1289(\mathrm{~m})$ & $\begin{array}{l}3359(\mathrm{sh}) \\
3218(\mathrm{sh}) \\
2940(\mathrm{sh})\end{array}$ & 1411(w) & - & $473(\mathrm{~m})$ & $408(\mathrm{~m})$ \\
\hline$[\mathrm{Mo}(\mathrm{salenH} 2)(\mathrm{Abtz})](6)$ & 3427 (b) & - & \begin{tabular}{|c|}
$1615(\mathrm{~s})$ \\
$1542(\mathrm{w})$
\end{tabular} & $1292(\mathrm{~m})$ & $3280(\mathrm{sh})$ & - & - & $\begin{array}{l}488 \\
(w)\end{array}$ & $409(w)$ \\
\hline
\end{tabular}

$a_{\text {s, strong; m, medium; } w \text {, weak; } b, \text { broad. }}$<smiles>CC12CN3CCN(Cc4ccccc4O1)C2(C)Oc1ccccc1O3</smiles>

$[\mathrm{Cr}(\mathrm{CO})($ salen) $(\mathrm{Tu})](1)$

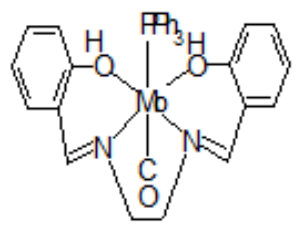

$\left[\mathrm{Mb}(\mathrm{CO})\left(\mathrm{salen}_{2}\right)\left(\mathrm{PPh}_{3}\right)\right](4)$<smiles></smiles>

$[\mathrm{Cr}($ salen $)(\mathrm{L})]\left(\mathrm{L}=\mathrm{PPh}_{3}(2) \propto \mathrm{Abtz}(3)\right)$

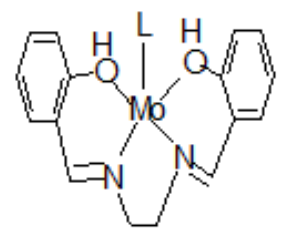

$\left[\mathrm{Mb}\left(\operatorname{salen} \mathrm{L}_{2}\right)(\mathrm{L})\right](\mathrm{L}=\mathrm{Tu}(5) \propto \mathrm{Abtz}(6))$

\section{Scheme1.}

\subsection{Magnetic Susceptibility}

Magnetic measurements of the complexes 1,2 and 3 at $298 \mathrm{~K}$ gave a value of an effective magnetic moment of 2.80, 2.77 and $2.86 \mathrm{BM}$, respectively. These values are close to the spin only moment of two unpaired electrons (2.84 $\mathrm{BM}$ ). Therefore, the paramagnetic chromium complexes would contain $\mathrm{Cr}$ (II) with a low-spin d4 configuration. Magnetic studies of the molybdenum complexes, 4-6, showed diamagnetic characteristics.

\subsection{Electron Spin Resonance}

The ESR spectrum for the [Cr (CO) (salen) (Tu)] and [Cr (salen) (Abtz)] complexes (Fig. 1, 2) gave a single broad signal with isotropic $\langle\mathrm{g}>$ value of 1.978 and 2.135 with no hyperfine structure, respectively. 
ESR spectrum of a powdered sample of the [Cr (salen)(PPh3)] complex (Fig. 3) gave two broad signals with isotropic $\langle\mathrm{g}>$ value of 2.109 and 2.340 with no hyperfine structure. The absence of hyperfine structure was indicative of no magnetic interaction between the chromium nucleus and the surrounding nuclei of ligand. The broadening of the signal obtained could be due to intramolecular spin exchange of the unpaired electrons.

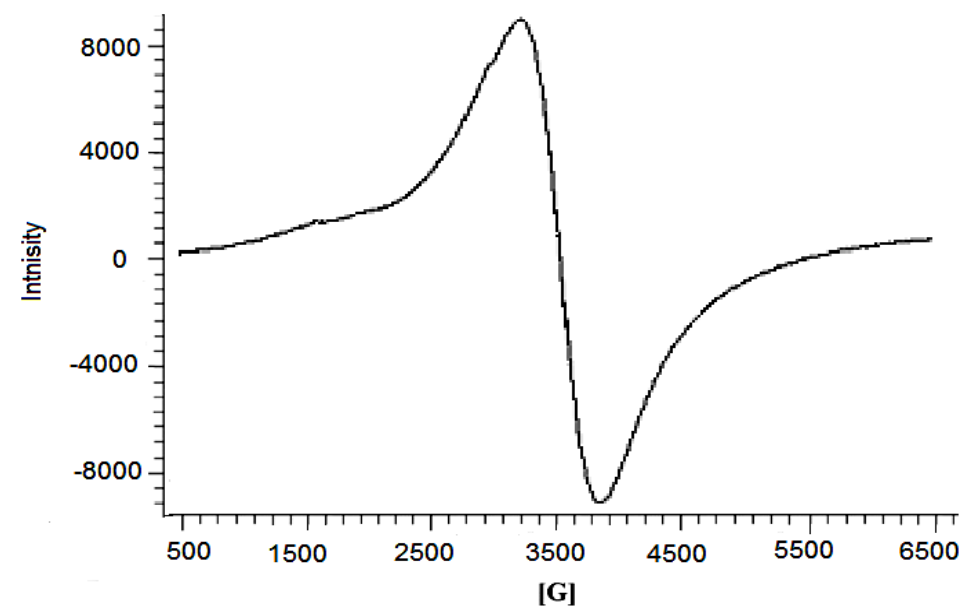

Fig1. The ESR spectrum of $[\mathrm{Cr}(\mathrm{CO})($ salen $)(\mathrm{Tu})]$ complex

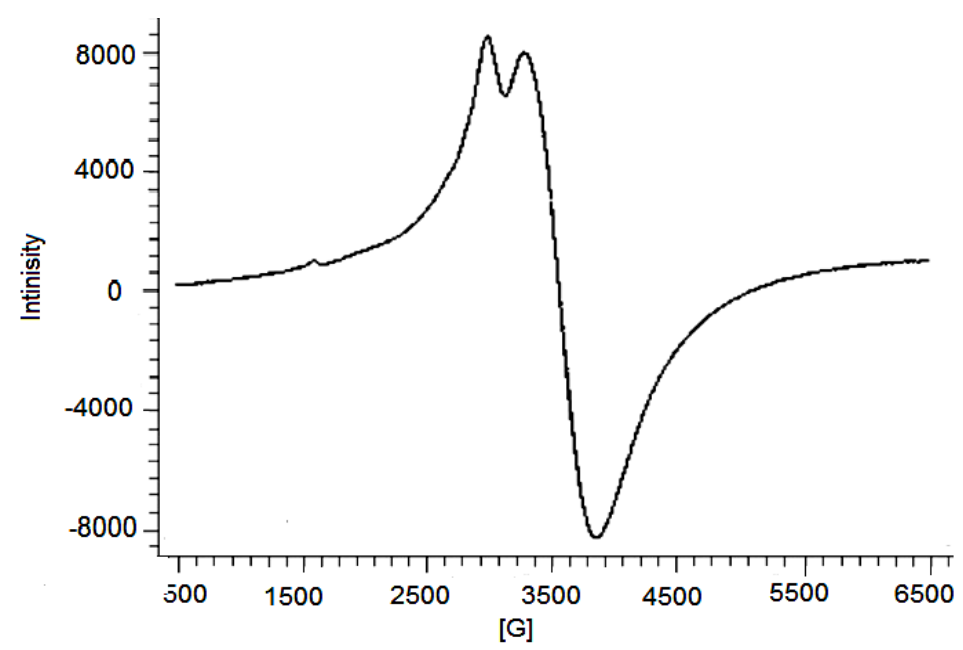

Fig2. The ESR spectrum of $\left[\mathrm{Cr}(\right.$ salen $\left.)\left(\mathrm{PPh}_{3}\right)\right]$ complex

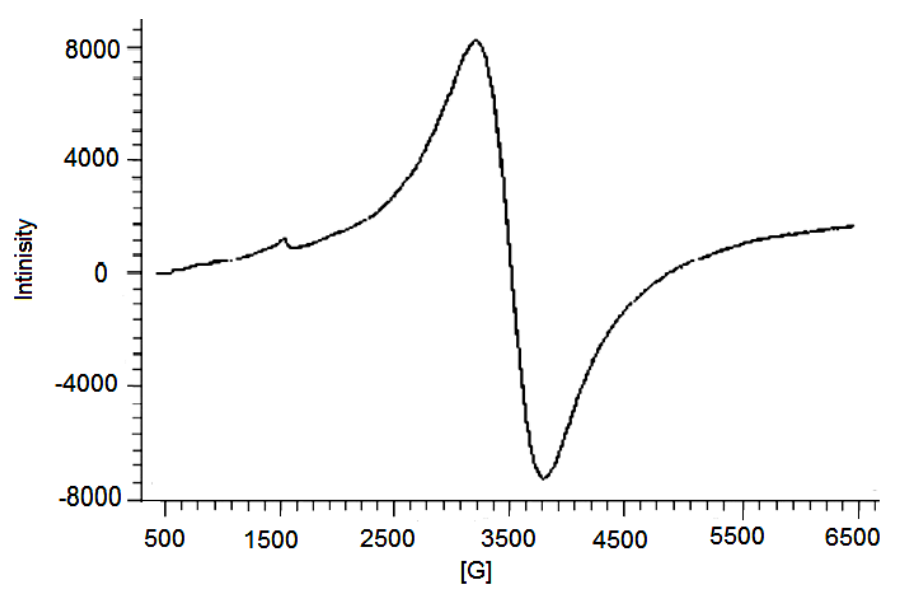

Fig3. The ESR spectrum of [Cr (salen)(Abtz)] complex 
Synthesis, Spectral, Thermal and Magnetic Studies of Chromium and Molybdenum Carbonyl Complexes Containing N2O2 Donor Sites

\section{4. ${ }^{1}$ H NMR Spectral Studies}

The 1H NMR spectra of the molybdenum complexes, 4-6, were recorded to confirm the binding of Schiff base to the molybdenum atom (Table 3 ). Spectra of the complexes showed a single in the region $\delta 8.59$ $8.99 \mathrm{ppm}$, which has been assigned to azomethine proton $(>\mathrm{CH}=\mathrm{N})$. The position of azomethine signal in the complexes is downfield in comparison with that of the salenH2 ligand, suggesting deshielding of the azomethine proton due to its coordination to molybdenum through the azomethine nitrogens. Multiplets are observed around $\delta 6.45-7.72 \mathrm{ppm}$ in 4-6 complexes have been assigned to aromatic protons of triphenylphosphine, 2-aminobenzothiazole and Schiff base ligand. The spectra of 4-6 showed a broad signal at 13.30-13.40 ppm indicating the presence of $\mathrm{OH}$ groups. According to the proposed structure, molybdenum may have zero formal oxidation state with d6 electronic configuration. A similar structure was obtained from the reaction of Mo $(\mathrm{CO}) 6$ with salenH2 in the presence of a secondary ligand $\mathrm{L}$ $(\mathrm{L}=\mathrm{H} 2 \mathrm{O}$, pyridine) resulted in the formation of the square pyramidal complex $\mathrm{M}(\mathrm{L})$ (salenH2) [27].

Table3. The important ${ }^{1}$ H NMR data for ligands and their complexes

\begin{tabular}{|c|c|}
\hline Compound & $\mathbf{1}_{\mathbf{H} ~ N M R ~(p p m)} \mathbf{a}$ \\
\hline salenH 2 & $2.50(\mathrm{t}, \mathrm{CH} 2), 6.84-7.42(\mathrm{~m}, \mathrm{Ph}), 8.59(\mathrm{~s}, \mathrm{CH}), 13.35(\mathrm{~s}, \mathrm{OH})$ \\
\hline $\mathrm{PPh} 3$ & $7.4(\mathrm{~m}, \mathrm{Ph}), 7.37(\mathrm{~m}, \mathrm{Ph})$ \\
\hline $\mathrm{Tu}$ & $7.02(\mathrm{bs}, \mathrm{NH} 2)$ \\
\hline $\mathrm{Abtz}$ & $6.98(\mathrm{t}, \mathrm{Ph}), 7.20(\mathrm{t}, \mathrm{Ph}), 7.34(\mathrm{~d}, \mathrm{Ph}), 7.42(\mathrm{~s}, \mathrm{NH} 2), 7.64(\mathrm{~d}, \mathrm{Ph})$ \\
\hline$[\mathrm{Mo}(\mathrm{CO})(\mathrm{salenH} 2)(\mathrm{PPh} 3)](4)$ & $2.50(\mathrm{t}, \mathrm{CH} 2), 7.05(\mathrm{~m}, \mathrm{Ph}), 7.62(\mathrm{~m}, \mathrm{Ph}), 8.61(\mathrm{~s}, \mathrm{CH}), 13.30(\mathrm{~b}, \mathrm{OH})$ \\
\hline$[\mathrm{Mo}(\mathrm{salenH} 2)(\mathrm{Tu})](5)$ & $2.49(\mathrm{t}, \mathrm{CH} 2), 6.86-7.56(\mathrm{~m}, \mathrm{Ph}), 8.59(\mathrm{~s}, \mathrm{CH}), 13.4(\mathrm{~b}, \mathrm{OH})$ \\
\hline$[\mathrm{Mo}(\mathrm{salenH} 2)(\mathrm{Abtz})](6)$ & $2.50(\mathrm{t}, \mathrm{CH} 2), 6.45-7.72(\mathrm{~m}, \mathrm{Ph}), 8.55(\mathrm{~s}, \mathrm{NH} 2), 8.99(\mathrm{~s}, \mathrm{CH}), 13.34(\mathrm{~s}, \mathrm{OH})$ \\
\hline
\end{tabular}

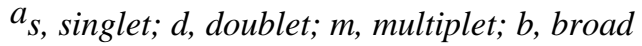

\subsection{Electronic absorption spectra}

The electronic absorption spectra of ligands and their complexes were investigated in DMF. On going from ligands to their complexes an appropriate shift were exerted in the $\pi-\pi^{*}$ and $n-\pi^{*}$ transitions (Table 4). The complexes 1, 3, 5 and 6 showed additional absorptions in the range 430-527 $\mathrm{nm}$ which could be due to charge transfer transitions [28].

Table4. The UV-vis. data (DMF) for ligands and their complexes

\begin{tabular}{|c|c|c|c|}
\hline \multirow{2}{*}{ Compound } & \multicolumn{3}{|c|}{$\square \mathbf{m a x}(\mathbf{n m})^{\mathbf{a}}$} \\
\cline { 2 - 4 } & $\square-\square *$ & $\mathbf{n}-\square *$ & charge transfer $^{*}$ \\
\hline salenH2 & 265 & 314 & - \\
\hline $\mathrm{Tu}$ & 285 & - & - \\
\hline $\mathrm{PPh} 3$ & 297,307 & - & - \\
\hline $\mathrm{Abtz}$ & 298 & $355(\mathrm{~b})$ & $527(\mathrm{~b})$ \\
\hline$[\mathrm{Cr}(\mathrm{CO})(\mathrm{salen})(\mathrm{Tu})](1)$ & 284 & 385 & - \\
\hline$[\mathrm{Cr}(\mathrm{salen})(\mathrm{PPh} 3)](2)$ & 275,280 & $384(\mathrm{~b})$ & $526(\mathrm{~b})$ \\
\hline$[\mathrm{Cr}(\mathrm{salen})(\mathrm{Abtz})](3)$ & 283 & 383 & - \\
\hline$[\mathrm{Mo}(\mathrm{CO})(\mathrm{salenH})(\mathrm{PPh} 3)](4)$ & 283 & $384(\mathrm{~b})$ & \\
\hline
\end{tabular}

$a_{\text {sh, shoulder; } b, \text { broad. }}$

\subsection{Thermal analysis}

TG/DTG curves have been studied for all complexes. The decomposition stages, temperature range, decomposition product as well as the found and calculated weight loss temperatures of the metal complexes are given in Tables (5-6). Thermal results show good agreement with the theoretical formula as suggested from the analytical data (Table 1).

The thermo gravimetric studies of $[\mathrm{Cr}(\mathrm{CO})$ (salen) (Tu)] (1) complex displayed that it was decomposed into fifth steps. The successive weight losses were observed in the temperature range 423.1-1234.8 K that ended with the formation of the metallic oxide $\mathrm{CrO} 2$ (Table 5) 
Synthesis, Spectral, Thermal and Magnetic Studies of Chromium and Molybdenum Carbonyl Complexes Containing N2O2 Donor Sites

The TG plot of [Cr (salen)(PPh3)] (2) complex showed that it decomposed in four steps. The first step consisted of four weak overlapped peaks in the temperature range 322.14-600.3 $\mathrm{K}$ with a percentage loss of $13.50 \%$ (Table 5). The second step appeared as a strong and resolved peak and occurred in the temperature range 600.3-880.7 $\mathrm{K}$ with a weight loss of 37.20\%. The third and fourth decomposition steps consisted of two unresolved peaks in the temperature ranges 880.7-1041.3 and 1041.3-1236.2 K.

The complex [Cr(salen)(Abtz)] (3) was decomposed in one step in the range 577.5-751.7 $\mathrm{K}$ with a loss of $81.88 \%$ was assumed to be due to the loss of $\mathrm{C} 23 \mathrm{H} 20 \mathrm{~N} 4 \mathrm{~S}$ species leaving $\mathrm{CrO} 2$ (Table 5).

Table5. Thermal analysis data for chromium complexes.

\begin{tabular}{|c|c|c|c|c|c|c|}
\hline \multirow[t]{2}{*}{ Molecular formula } & \multirow[t]{2}{*}{ M.wt. } & \multirow{2}{*}{$\begin{array}{c}\text { Decomposition } \\
\text { temperature } \\
(\mathbf{K})\end{array}$} & \multicolumn{2}{|c|}{ \% Weight loss } & \multirow{2}{*}{$\begin{array}{l}\text { Eliminated } \\
\text { species }\end{array}$} & \multirow{2}{*}{$\begin{array}{l}\text { \% Solid } \\
\text { residue } \\
\text { (found) }\end{array}$} \\
\hline & & & Calculated & Found & & \\
\hline $\begin{array}{c}\mathrm{Cr}(\mathrm{CO})\left(\mathrm{C}_{16} \mathrm{H}_{14} \mathrm{~N}_{2} \mathrm{O}_{2}\right) \\
\quad\left(\mathrm{CH}_{4} \mathrm{~N}_{2} \mathrm{~S}\right)(1)\end{array}$ & 422.42 & $\begin{array}{c}423.1-574.6 \\
594.7-774.6 \\
762.6-874.7 \\
914.5-1034.6 \\
1094.7-1234.8 \\
\end{array}$ & $\begin{array}{l}13.44 \\
22.60 \\
13.08 \\
15.52 \\
16.08 \\
\end{array}$ & $\begin{array}{l}13.26 \\
22.05 \\
13.28 \\
15.17 \\
16.36 \\
\end{array}$ & $\begin{array}{c}\mathrm{CO}+\mathrm{N}_{2} \\
\mathrm{C}_{7} \mathrm{H}_{9} \\
\mathrm{C}_{2} \mathrm{~S} \\
\mathrm{C}_{5} \mathrm{H}_{4} \\
\mathrm{C}_{3} \mathrm{H}_{5} \mathrm{~N}_{2} \\
\end{array}$ & $\begin{array}{c}\mathrm{CrO}_{2} \\
(19.28)\end{array}$ \\
\hline $\mathrm{Cr}\left(\mathrm{C}_{16} \mathrm{H}_{14} \mathrm{~N}_{2} \mathrm{O}_{2}\right)\left(\mathrm{C}_{6} \mathrm{H}_{5}\right)_{3} \mathrm{P}(2)$ & 580.55 & $\begin{array}{c}322.14-600.3 \\
600.3-880.7 \\
880.7-1041.3 \\
1041.3-1236.2 \\
\end{array}$ & $\begin{array}{l}13.50 \\
37.20 \\
18.33 \\
16.42 \\
\end{array}$ & $\begin{array}{l}13.63 \\
37.08 \\
18.45 \\
16.37 \\
\end{array}$ & $\begin{array}{c}\mathrm{C}_{6} \mathrm{H}_{7} \\
\mathrm{C}_{17} \mathrm{H}_{11} \\
\mathrm{C}_{6} \mathrm{H}_{7} \mathrm{~N}_{2} \\
\mathrm{PC}_{5} \mathrm{H}_{4} \\
\end{array}$ & $\begin{array}{c}\mathrm{CrO}_{2} \\
(14.55)\end{array}$ \\
\hline $\mathrm{Cr}\left(\mathrm{C}_{16} \mathrm{H}_{14} \mathrm{~N}_{2} \mathrm{O}_{2}\right)\left(\mathrm{C}_{7} \mathrm{H}_{6} \mathrm{~N}_{2} \mathrm{~S}\right)(3)$ & 468.48 & $577.5-751.7$ & 81.88 & 82.07 & $\mathrm{C}_{23} \mathrm{H}_{20} \mathrm{~N}_{4} \mathrm{~S}$ & $\begin{array}{c}\mathrm{CrO}_{2} \\
(18.12)\end{array}$ \\
\hline
\end{tabular}

The TG plot of [Mo (CO) (salenH2) (PPh3)] (4) complex showed that it was decomposed in four steps. The successive weight losses were observed in the temperature range 327.23-1157.1 K (Table 6). The first and third steps appeared as weak overlapped peaks in the temperature ranges 327.23-437.2 and 577.8-1037.3 K with net weight losses of 4.21 and $34.80 \%$, respectively. The second and fourth decomposition steps consisted of two resolved peaks. These four steps were corresponded to significant material decomposition to yield the metallic oxide $\mathrm{MoO} 3$.

The TG plot of [Mo (salenH2) (Tu)] (5) complex showed that it was decomposed in two unresolved and one strong resolved steps. The first decomposition peak occurred at 393.5-513.8 K with a net weight loss $13.46 \%$. The percentage weight loss was consistent with the elimination of NH2CS. The second decomposition peak occurred at 513.8-978.8 K could be attributed to loss of C9H13N2 species. The third decomposition step occurred in the temperature range 998.9-1248 $\mathrm{K}$ with a weight loss of $23.85 \%$ that ended with the formation of $\mathrm{MoO} 2$ (Table 6).

The [Mo (salenH2)(Abtz)] (6) complex was found to thermally decompose in three steps. The first step occurred at 526.6-706.4 K with a net weight loss $14.50 \%$. The second step appeared as a resolved peak with a weight loss of $47.34 \%$. The third decomposition step consisted of strong resolved peaks in the temperature ranges 1186.7-1246.6 K with net weight losses of $13.33 \%$ (Table 6).

Table6. Thermal analysis data for molybdenum complexes.

\begin{tabular}{|c|c|c|c|c|c|c|}
\hline \multirow[t]{2}{*}{ Molecular formula } & \multirow[t]{2}{*}{ M.wt. } & \multirow{2}{*}{$\begin{array}{c}\text { Decomposition } \\
\text { temperature } \\
\text { (K) }\end{array}$} & \multicolumn{2}{|c|}{ \% Weight loss } & \multirow{2}{*}{$\begin{array}{l}\text { Eliminated } \\
\text { species }\end{array}$} & \multirow{2}{*}{$\begin{array}{l}\text { \% Solid } \\
\text { residue } \\
\text { (found) }\end{array}$} \\
\hline & & & Found & Calculated & & \\
\hline $\mathrm{Mo}(\mathrm{CO})\left(\mathrm{C}_{16} \mathrm{H}_{16} \mathrm{~N}_{2} \mathrm{O}_{2}\right)\left(\mathrm{C}_{6} \mathrm{H}_{5}\right)_{3} \mathrm{P}$ & 654.53 & $\begin{array}{c}327.23-437.2 \\
437.2-577.8 \\
577.8-1037.3 \\
1037.3-1157.1 \\
\end{array}$ & $\begin{array}{c}4.21 \\
27.11 \\
34.80 \\
11.72 \\
\end{array}$ & $\begin{array}{c}4.28 \\
27.23 \\
34.60 \\
11.93 \\
\end{array}$ & $\begin{array}{c}\mathrm{N}_{2} \\
\mathrm{C}_{14} \mathrm{H}_{10} \\
\mathrm{C}_{15} \mathrm{H}_{15} \mathrm{P} \\
\mathrm{C}_{6} \mathrm{H}_{6} \\
\end{array}$ & $\begin{array}{l}\mathrm{MoO}_{3} \\
(22.16)\end{array}$ \\
\hline $\mathrm{Mo}\left(\mathrm{C}_{16} \mathrm{H}_{16} \mathrm{~N}_{2} \mathrm{O}_{2}\right)\left(\mathrm{CH}_{4} \mathrm{~N}_{2} \mathrm{~S}\right)(5)$ & 440.37 & $\begin{array}{l}393.5-513.8 \\
513.8-978.8 \\
998.9-1248 \\
\end{array}$ & $\begin{array}{l}13.46 \\
33.03 \\
23.85 \\
\end{array}$ & $\begin{array}{l}13.65 \\
33.88 \\
23.41\end{array}$ & $\begin{array}{c}\mathrm{NH}_{2} \mathrm{CS} \\
\mathrm{C}_{9} \mathrm{H}_{13} \mathrm{~N}_{2} \\
\mathrm{C}_{7} \mathrm{H}_{5} \mathrm{~N}\end{array}$ & $\begin{array}{l}\mathrm{MoO}_{2} \\
(29.66)\end{array}$ \\
\hline $\begin{array}{c}\mathrm{Mo}\left(\mathrm{C}_{16} \mathrm{H}_{16} \mathrm{~N}_{2} \mathrm{O}_{2}\right)\left(\mathrm{C}_{7} \mathrm{H}_{6} \mathrm{~N}_{2} \mathrm{~S}\right) \\
(6)\end{array}$ & 514.44 & $\begin{array}{c}526.6-706.4 \\
706.4-1186.7 \\
1186.7-1246.6\end{array}$ & $\begin{array}{l}14.50 \\
47.34 \\
13.33 \\
\end{array}$ & $\begin{array}{l}14.80 \\
47.29 \\
13.04\end{array}$ & $\begin{array}{c}\mathrm{CH}_{4} \mathrm{~N}_{2} \mathrm{~S} \\
\mathrm{C}_{17} \mathrm{H}_{11} \mathrm{~N}_{2} \\
\mathrm{C}_{5} \mathrm{H}_{7}\end{array}$ & $\begin{array}{l}\mathrm{MoO}_{2} \\
(24.83)\end{array}$ \\
\hline
\end{tabular}

International Journal of Advanced Research in Chemical Science (IJARCS) 
The activation energy $\mathrm{E}^{*}$ of the various decomposition stages for the complexes were determined from the TG and DTG themograms using the Coats-Redfern equation in the following form:

$$
\log \left[\frac{\log \left(W_{\infty} /\left(W_{\infty}-W\right)\right)}{T^{2}}\right]=\log \left[\frac{A R}{\phi E^{*}}\left(1-\frac{2 R T}{E^{*}}\right)\right]-\frac{E^{*}}{2.303 R T}
$$

Where $\mathrm{W} \infty$ is the mass loss at the completion of the decomposition reaction, $\mathrm{W}$ is the mass loss up to temperature T, R is the gas constant and $\phi$ is the heating rate. Since $1-2 \mathrm{RT} / \mathrm{E}^{*} \cong 1$, the plot of the lefthand side of equation (1) against $1 / \mathrm{T}$ would give a straight line. $\mathrm{E}^{*}$ was then calculated from the slope and the Arrhenius constant, A, was obtained from the intercept. The other kinetic parameters; the entropy of activation $\left(\mathrm{S}^{*}\right)$, enthalpy of activation $\left(\mathrm{H}^{*}\right)$ and the free energy change of activation $\left(\mathrm{G}^{*}\right)$ were calculated using the relationships:

$$
\begin{aligned}
S^{*} & =2303\left(\log \frac{A h}{K T}\right) R \\
\mathbf{H}^{*} & =\mathrm{E}^{*}-\mathbf{R T} \\
\mathrm{G}^{*} & =\mathrm{H}^{*}-\mathrm{T}_{\mathrm{S}} \mathrm{S}^{*}
\end{aligned}
$$

Where, (k) and (h) are the Boltzman and Planck constants, respectively. The kinetic parameters are listed in Table (7). The correlation coefficients of the Arrhenius plots of the thermal decomposition stages were

\begin{tabular}{|c|c|c|c|c|c|}
\hline Complex & $\begin{array}{l}\text { Decomposition } \\
\text { Temperature/K }\end{array}$ & $\mathrm{E}^{*} / \mathrm{kJmol}^{-1}$ & $\mathrm{~S}^{*} / \mathrm{K}^{-1} \mathrm{Jmol}^{-1}$ & $\mathrm{H}^{*} / \mathrm{kJmol}^{-1}$ & $\mathrm{G}^{*} / \mathrm{kJmol}^{-1}$ \\
\hline \multirow[t]{5}{*}{$\mathrm{Cr}(\mathrm{CO})($ salen$)(\mathrm{Tu})(1)$} & $423.1-594.7$ & 23.81 & -229.25 & 19.69 & 133.08 \\
\hline & $594.7-774.6$ & 25.19 & -241.65 & 19.58 & 182.67 \\
\hline & $774.6-874.7$ & 27.64 & -244.12 & 20.86 & 219.75 \\
\hline & $914.5-1034.6$ & 28.34 & -253.25 & 19.90 & 276.92 \\
\hline & $1094.7-1234.8$ & 47.40 & -241.87 & 37.08 & 317.04 \\
\hline \multirow[t]{3}{*}{$\mathrm{Cr}($ salen$)(\mathrm{PPh} 3)(2)$} & $600.3-880.7$ & 31.52 & -238.98 & 25.52 & 197.78 \\
\hline & $880.7-1041.3$ & 29.25 & -253.27 & 20.92 & 274.51 \\
\hline & $1041.3-1236.2$ & 53.21 & -231.81 & 44.05 & 299.38 \\
\hline Cr(salen)(Abtz) (3) & $577.5-751.7$ & 81.70 & -147.35 & 76.15 & 174.49 \\
\hline \multirow[t]{2}{*}{$\mathrm{Mo}(\mathrm{CO})($ salenH2)(PPh3) (4) } & $437.2-577.8$ & 33.58 & -205.80 & 29.27 & 135.72 \\
\hline & $1037.3-1157.1$ & 92.00 & -188.87 & 83.04 & 286.60 \\
\hline \multirow{3}{*}{$\mathrm{Mo}($ salenH2)(Tu) (5) } & $393.5-513.8$ & 39.56 & -185.21 & 35.62 & 123.37 \\
\hline & $513.8-663.8$ & 22.77 & -236.33 & 17.83 & 158.16 \\
\hline & 998.9-1248 & 42.31 & -245.11 & 33.17 & 302.37 \\
\hline \multirow{3}{*}{ Mo(salenH2)(Abtz) (6) } & $496.7-706.4$ & 28.72 & -230.41 & 23.84 & 158.95 \\
\hline & $706.4-1186.7$ & 16.19 & -275.85 & 8.32 & 269.52 \\
\hline & $1186.7-1246.6$ & 134.16 & -164.21 & 123.79 & 328.49 \\
\hline
\end{tabular}
found to lie in the range 0.9974-0.9757 showing a good fit with the linear function. Additionally, the negative values of entropy indicate that activated complexes have more ordered systems than reactants [29].

Table7. The kinetic and thermodynamic data of the thermal decompositions of complexes

\subsection{Antimicrobial activity}

The Schiff base ligand and its metal complexes were evaluated for antimicrobial activity against Gram positive bacteria (S. aureus), Gram negative bacteria (E. coli) and fungi (C. albicans and A. flavus) and the results are summarized in Table 8. The salenH 2 and complexes was found to be biologically active. The remarkable result is that the complexes 1-3 showed lower inhibition against E. coli and $\mathrm{S}$. aureus as compared with complexes 4-6. Also, complexes 1, 4 and 6 showed higher activity against the fungi C. albicans and A. flavus. The enhanced activity of the metal complexes may be ascribed to the increased lipophilic nature of the complexes arising due to chelation. It is probably due to faster diffusion of the chelates as a whole through the cell membrane or due to the chelation theory. 
Synthesis, Spectral, Thermal and Magnetic Studies of Chromium and Molybdenum Carbonyl Complexes Containing N2O2 Donor Sites

Table8. Biological activities of salenH2 and its chromium and molybdenum complexes

\begin{tabular}{|c|c|c|c|c|}
\hline \multirow[t]{2}{*}{ Compound } & \multicolumn{4}{|c|}{ Diameter of inhibition zone (mm) } \\
\hline & $\begin{array}{c}\text { Escherichia coli } \\
\text { (G-) }\end{array}$ & $\begin{array}{c}\text { Staphylococcus aureus } \\
(\mathbf{G}+)\end{array}$ & $\begin{array}{c}\text { Aspergillus } \\
\text { flavus (Fungus) }\end{array}$ & $\begin{array}{c}\text { Candida albicans } \\
\text { (Fungus) }\end{array}$ \\
\hline salenH2 & 13 & 13 & 11 & 12 \\
\hline $\mathrm{Cr}(\mathrm{CO})($ salen$)(\mathrm{Tu})(1)$ & 34 & 30 & 31 & 34 \\
\hline $\mathrm{Cr}($ salen$)(\mathrm{PPh} 3)(2)$ & 9 & 9 & 0.0 & 0.0 \\
\hline $\mathrm{Cr}($ salen)(Abtz) (3) & 21 & 19 & 20 & 22 \\
\hline $\mathrm{Mo}(\mathrm{CO})($ salenH2)(PPh3) $(4$ & & & & \\
\hline Mo(salenH2)(Tu) (5) & & & & \\
\hline Mo(salenH2)(Abtz) (6) & 21 & 16 & 18 & 16 \\
\hline $\begin{array}{c}\text { Tetracycline } \\
\text { Antibacterial agent }\end{array}$ & 34 & 31 & - & - \\
\hline $\begin{array}{l}\text { Amphotericin B } \\
\text { Antifungal agent }\end{array}$ & - & - & 18 & 20 \\
\hline
\end{tabular}

\section{REFERENCES}

[1] Ray, M. S., Chattopadhyay, S., Drew, M.G.B., Figuerola, A., Ribas, J., Diaz, C., Ghosh, A., Eur. J. Inorg. Chem. 22, 4562 (2005);

[2] Bian, H.D., Xu, J.Y., Gu, W., Yan, S.P., Cheng, P., Liao, D.Z., Jiang, Z.H. , Polyhedron 22, 2927 (2003);

[3] Banerjee, S., Lassahn, P.G., Janiak, C., Ghosh, A., Polyhedron 24, 2963 (2005);

[4] Ray, M.S., Mukhopadhyay, G.C., drew, M.G.B., Lu, T.H., Chaudhuri, S., Ghosh, A., Inorg. Chem. Commun. 6, 961(2003);

[5] Chattopadhyay, S., Chakraborty, P., Drew, M.G.B., Ghosh, A., Inorg. Chim. Acta. 362, 502 (2009);

[6] Abdel-Latif, S.A., Hassib, H.B., Issa, Y.M., Spectrochim. Acta Part A 67, 950 (2007);

[7] Ngan, N.K., Lo, K.M., Wong, C.S.R., Polyhedron 30, 2922 (2011).

[8] Sigel, A., in: Sigel, H. (Ed.), Metal ions in biological systems, 32, Marcel Dekker, New York, 1996;

[9] Shahabadi, N., Kashanian, S., Darabi, F., Eur. J. Med. Chem. 45, 4239 (2010).

[10] Erkkila, K.E., Odom, D.T., Barton, J.K., Chem. Rev. 99, 2777 (1999).

[11] Metcalfe, C., Thomas, J.A., Chem. Soc. Rev. 32, 215 (2003).

[12] Shebl, M., Khalil, S.M.E., Ahmed, S.A., Medien, H.A.A., J. Mol. Struct. 980, 39 (2010).

[13] Mishra, A.P., Jain, R.K., J. Chem. Pharm. Res. 2, 51 (2010).

[14] Mishra, A.P., Tiwari, A., Gupta, S.K., Jain, R., E-J. of Chem. 91113 (2012).

[15] Prakash, A., Singh, B.K., Bhojak, N., Adhikari, D., Spectrochim. Acta Part A 76, 356 (2010).

[16] Small, B.L., Schmidt, R., Chem. Eur. J. 10 1014, (2004);

[17] Ionkin, A.S., Marshall, W.J., J. Organomet. Chem. 689, 1057 (2004);

[18] Gibson, V.C., Spitzmesser, S.K., Chem. Rev. 103, 283 (2003);

[19] McGuiness, D.S., Wasserscheid, P., Keim, W., Morgan, D., Dixon, J.T., Bollman, A., Maumela, H., Hess, F., Englert, U., J. Am. Chem. Soc. 125, 5272 (2003);

[20] Gatteschi, D., Sessoli, R., Angew. Chem. 115, 278 (2003);

[21] Winpenny, R.E.P., Adv. Inorg. Chem. 52, 1 (2001);

[22] Boskovic, C., Brechin, E.K., Streib, W.E., Folting, K., Bollinger, J.C., Hendrickson, D.N., Christou, G., J. Am. Chem. Soc. 124, 725 (2002);

[23] Chandra, S., Sharma, A.K., J. Coord. Chem. 62, 3688 (2009); Chun, L., Kagan, C.R., J. Am. Chem. Soc. 125, 336 (2003);

[24] Toma, H.E., J. Braz. Chem. Soc. 14, 845 (2003);

[25] Holm, R.H., J. Am. Chem. Soc. 82, 5632 (1960).

[26] Rosu, T., Pahontu, E., Maxim, C., Georgescu, R., Stanica, N., Gulea, A., Polyhedron 30, 154 (2011).

[27] Prashanthi Y., Kiranmai, K., Ira, Sathish, K.K., Chityala, V.K., Shivaraj, Bioinorg. Chem. and Appl. (2012) doi:10.1155/2012/948534. 
Synthesis, Spectral, Thermal and Magnetic Studies of Chromium and Molybdenum Carbonyl Complexes Containing $\mathrm{N}_{2} \mathrm{O}_{2}$ Donor Sites

[28] Srinivasan, K., Michaud, P., Kochi, J.K., J. Am. Chem. Soc. 108, 2309 (1986).

[29] Zhang, W., Loebach, J.L., Wilson, S.R., Jacobsen, E.N., J. Am. Chem. Soc. 112, 2801 (1990).

[30] Tisato, J., Refosco, F., Bandoli, F., Coord. Chem. Rev. 135, 325 (1994).

[31] Lacroix, J., Eur. J. Inorg. Chem. 2, 339 (2001).

[32] Nagel, J., Oertel, U., Friedel, P., Komber, H., Mobius, D., Langmuir 13, 4698 (1997).

[33] Sundari, S.S., Dhathathreyan, A., Kanthimathi, M., Balachandran, U.N., Langmuir 13, 4923 (1997).

[34] Ali, O.A.M., Laila, H.A.R., Ramadan, R.M., J. Coord. Chem. 60, 2335 (2007).

[35] Ali, O.A.M., J. Coord. Chem. 60, 1213 (2007).

[36] Ali, O.A.M., Khalil, M.M.H., Attia, G.M., Ramadan, R.M., J. Spectroscopy Lett. 36, 71 (2003).

[37] EL-Medani, S.M., Ali, O.A.M., Ramadan, R.M., J. Mol. Struct. 738, 171 (2005).

[38] Ramadan, R.M., Hamza, M.S.A., Ali, S.A., J. Coord. Chem. 43, 31 (1998).

[39] Ali, S.A., Soliman, A.A., Aboaly, M.M., Ramadan, R.M., J. Coord. Chem. 55, 1161 (2002).

[40] Finar, I.L., Organic Chemistry $5^{\text {th }}$ Edn, Longman, London, 1967.

[41] Nakamoto, K., Infrared and Raman Spectra of Inorganic and Coordination Compounds, 4th Edn. Wiley, New York, 1986.

[42] Collman, J.and Hegedus, L.S., Principles and Application of Organ transition Metal Chemistry (University Science, California, 1980)

[43] El-Medani, S.M., J. Coord. Chem. 57, 497 (2004).

[44] Abd El-Wahab, Z.H., Mashaly, M.M., Salman, A.A., El-Shetary, B.A., Faheim, A.A., Spectrochim. Acta Part A 60, 2861 (2004).

[45] Sabry, D.Y., Youssef, T.A., EL-Medani, S.M., Ramadan, R.M., Coord. Chem. 56, 1375 (2003).

[46] Khalil, M.M.H., Mohamed, H.A., El-Medani, S.M., Ramadan, R.M., Spectrochim. Acta Part A 59, 1341 (2003).

[47] Mohamed, G.G. Abd El-Wahab, Z.H, Spectrochim. Acta Part A 61, 1059 (2005).

Citation: Omyma A. M. Ali, et.al, "Synthesis, Spectral, Thermal and Magnetic Studies of Chromium and Molybdenum Carbonyl Complexes Containing N2O2 Donor Sites", International Journal of Advanced Research in Chemical Science, vol. 6, no. 9, p. 1-10, 2019. DOI: http://dx.doi.org/10.20431/2349-0403.0609001

Copyright: ( 2019 Authors. This is an open-access article distributed under the terms of the Creative Commons Attribution License, which permits unrestricted use, distribution, and reproduction in any medium, provided the original author and source are credited. 